\title{
Tracing the Impact of Agricultural Policies on Irrigation Water Demand and Groundwater Extraction in France
}

\author{
Author: Rouillard, J., BRGM, Montpellier University, Montpellier, \\ France
}

\begin{abstract}
Sustainable groundwater quantitative management does not only depend on implementing the right water policy instruments. It also relies on enabling sectoral policies that work in synergy with water policy objectives. To explore this link, this chapter presents the evolution of European agricultural policies, their level of support to irrigated farming, and consequences for groundwater abstraction in France. Three phases are identified. Until 1992, the French government encouraged the deployment of irrigated farming through price support mechanisms, market measures, subsidies for agricultural modernisation, and large scale supply infrastructure projects. The second phase, from 1992 and 2003, is a transitional period during which agricultural policies maintained an explicit support to irrigated farming, while the first agro-environmental schemes were established. The third and on-going phase (2003-2020) is associated with the progressive removal of direct payments for irrigated crops, while rural development funding offers mixed incentives. The chapter then presents current policy instruments contributing to reduce structural water deficits due to agricultural abstraction. To date, most projects to achieve groundwater quantitative targets focus on improvements in irrigation efficiency and the building of "compensatory" water storage schemes. To meet the challenges of climate change and increased scarcity, future initiatives should focus on water savings through the diversification of agricultural and food systems.
\end{abstract}

Keywords: groundwater pumping, irrigation, Common Agricultural Policy, mainstreaming, demand-side management, agri-food systems

\section{Introduction}

In France, the agricultural sector is responsible for around $20 \%$ of groundwater use and $30 \%$ of surface water use, but it is the largest annual net water consumer $(50 \%)$ and can represent up to $80 \%$ of total consumptive use in summer in some regions. About $40 \%$ of water abstracted annually for agriculture in the country is 
from groundwater (AFB, 2017). In central and western regions, groundwater represents the majority if not the only source of water (e.g. Beauce, see chapter 5).

The progressive tightening of abstraction controls in 1990s have posed significant challenges to irrigated agriculture in France. Farmers have invested in more efficient irrigation techniques as well as reservoirs to store winter flow for consumptive use during the summer period. Conflicts have nevertheless become frequent, especially in regions where irrigation is mainly used for intensive cereal production. Proponents of irrigated agriculture emphasise its role in enhancing crop productivity and the competitiveness of the sector as well as in reducing exposure to drought risks and stabilising farm income. Critics emphasise the impacts of abstraction on environmental flows, ecological continuity and natural habitats, the appropriation of water by an intensive form of agriculture, and the high cost of building water supply infrastructure.

To reduce conflicts and align water demand with available resources, French authorities have set quantitative targets for priority aquifers and catchments (Erdlenbruch et al, 2013). They also require a reduction of agricultural water allocations which must be mutualised and allocated annually to irrigators (see chapter 3 ). This approach largely assumes that farmers would adapt their choice of crop production and irrigation management according to their allocations. However, this perspective does not account for the sectoral incentives that work against water policy objectives and contribute to increase agricultural water demand.

This chapter posits that successful groundwater quantitative management is not only dependent on water policy instruments such as those reducing water allocations but also on enabling sectoral policies. It presents how, historically, agricultural price support mechanisms, market measures and subsidies for agricultural modernisation have largely contributed to promote irrigation and increase groundwater abstraction (Figure 1, Table 1). It also examines how reformed agricultural and rural development policies can contribute to reduce abstraction pressure and help reach quantitative management targets by encouraging changes in farm and irrigation management.

The chapter is organised in the following way. Section 2 presents a historical narrative (1950s-2010s) of how different agricultural and rural development policy phases have influenced the development of irrigation and consequently groundwater abstraction. Table 1 provides an overview of the policy instruments reviewed, their relationship with the development of irrigation, and their impact on groundwater. Section 3 presents current strategies used to reduce structural water deficits due to agricultural abstraction. The conclusion highlights opportunities and challenges for integrating groundwater quantitative management and agricultural policies in France. 
Table 1. Policy mechanisms influencing investment and maintenance of irrigation systems in France (Legend: ++: actively supports abstraction; + contributes to encourage abstraction; 0: neutral; -: reduces incentive to abstract)

\begin{tabular}{|c|c|c|}
\hline Key policy mechanism & $\begin{array}{l}\text { Impact on the development of irri- } \\
\text { gation }\end{array}$ & $\begin{array}{l}\text { Impact on ground- } \\
\text { water abstraction }\end{array}$ \\
\hline \multicolumn{3}{|c|}{ 1945-1992 } \\
\hline $\begin{array}{l}\text { EU market and price in- } \\
\text { terventions (CAP guar- } \\
\text { antee fund) }\end{array}$ & $\begin{array}{l}\text { Minimum commodity price and stable } \\
\text { income offer favourable grounds for } \\
\text { private investments in irrigation infra- } \\
\text { structure }\end{array}$ & + \\
\hline $\begin{array}{l}\text { National and European } \\
\text { structural funding for the } \\
\text { modernisation of agri- } \\
\text { cultural holdings }\end{array}$ & $\begin{array}{l}\text { Subsidies for targeted investments in } \\
\text { irrigation infrastructure }\end{array}$ & ++ \\
\hline \multicolumn{3}{|c|}{$1992-2003$} \\
\hline $\begin{array}{l}\text { Direct coupled payments } \\
\text { and irrigation premium }\end{array}$ & $\begin{array}{l}\text { Direct income support strengthens } \\
\text { farm-level investment capacity (e.g. } \\
\text { to develop new irrigation infrastruc- } \\
\text { ture) and cash flow to maintain exist- } \\
\text { ing infrastructure }\end{array}$ & ++ \\
\hline $\begin{array}{l}\text { Rural development plans } \\
\text {-investments }\end{array}$ & $\begin{array}{l}\text { Subsidies for targeted investments in } \\
\text { irrigation infrastructure }\end{array}$ & + \\
\hline $\begin{array}{l}\text { Rural development plans } \\
\text { (agri-environment pay- } \\
\text { ments) }\end{array}$ & $\begin{array}{l}\text { Compensation of income loss and ad- } \\
\text { ditional costs for the uptake of less } \\
\text { water intensive land use and manage- } \\
\text { ment practice }\end{array}$ & - \\
\hline \multicolumn{3}{|c|}{$2003-2020$} \\
\hline $\begin{array}{l}\text { Direct uncoupled pay- } \\
\text { ments }\end{array}$ & $\begin{array}{l}\text { Direct income support maintains in- } \\
\text { vestment capacity and cash flow, but } \\
\text { does not directly encourage increased } \\
\text { agricultural production }\end{array}$ & 0 \\
\hline Greening & $\begin{array}{l}\text { Payments rewarding crop diversifica- } \\
\text { tion, permanent grasslands and eco- } \\
\text { logical focus areas contribute to re- } \\
\text { duce incentive to farm water intensive } \\
\text { crops }\end{array}$ & - \\
\hline $\begin{array}{l}\text { Rural development } \\
\text { plans (investments) }\end{array}$ & $\begin{array}{l}\text { Subsidies for targeted investments in } \\
\text { irrigation infrastructure (additional } \\
\text { environmental conditionality and } \\
\text { funding of compensatory reservoirs) }\end{array}$ & $+/-$ \\
\hline $\begin{array}{l}\text { Rural development } \\
\text { plans (agri-environment } \\
\text { payments) }\end{array}$ & $\begin{array}{l}\text { Compensation of income loss and ad- } \\
\text { ditional costs for the uptake of less } \\
\text { water intensive land use and manage- } \\
\text { ment practice }\end{array}$ & - \\
\hline
\end{tabular}




\section{Irrigation development and groundwater use in France}

\section{Increasing food production through irrigation: 1945 to 1992}

Irrigation has long been an essential element of agriculture in the southern and drier Mediterranean regions of France. It was traditionally based on the diversion of surface river water into canals and applied through gravity to orchards, vegetable crops, and rice fields (in the Rhône delta). In other regions of France, surface irrigation was limited to areas with specific climatic, topographic or soil characteristics. Irrigated agricultural land increased significantly in the second half of the $20^{\text {th }}$ century, from 402,000 ha in 1955 to 539,000 ha in 1970 ( $+25 \%$ in 15 years). By this time, irrigation remained concentrated in southern France and could still be generally characterised as a form of "structural" irrigation, whereby irrigated water represents most water supply to the crop in the dry season. Yet, eighteen years later in 1988, irrigation reached 1,147,000 ha $(+112 \%)$ (Janin, 1996), expanding northwards and westwards (Figure 1) into regions where irrigation can be characterised as "complementary" because irrigated water mainly serves to control the timing and quality of crops.

The vast expansion of irrigation in France is associated with a pro-active policy to increase food production and the competitiveness of French agriculture on international markets (Rieu and Arlot, 1992; Brun et al., 2006). The EU Common Agricultural Policy (CAP) was launched in 1962, guaranteeing minimum commodity prices to European farmers. In parallel, a vigorous policy to modernise agriculture was initiated via subsidies for agricultural equipment and infrastructure such as irrigation schemes (Perrin et al., 2003; Dechambre, 2007). Thanks to CAP incentives, private investments and technical progress, food production increased by $64 \%$ between 1960 and 1980 and France became the second net exporter of food product worldwide in 1981 (Brun et al., 2006). CAP price support mechanisms particularly favoured cereal and maize production. By 1988, irrigated maize represented $48 \%$ of irrigated areas in France (Janin, 1996). 


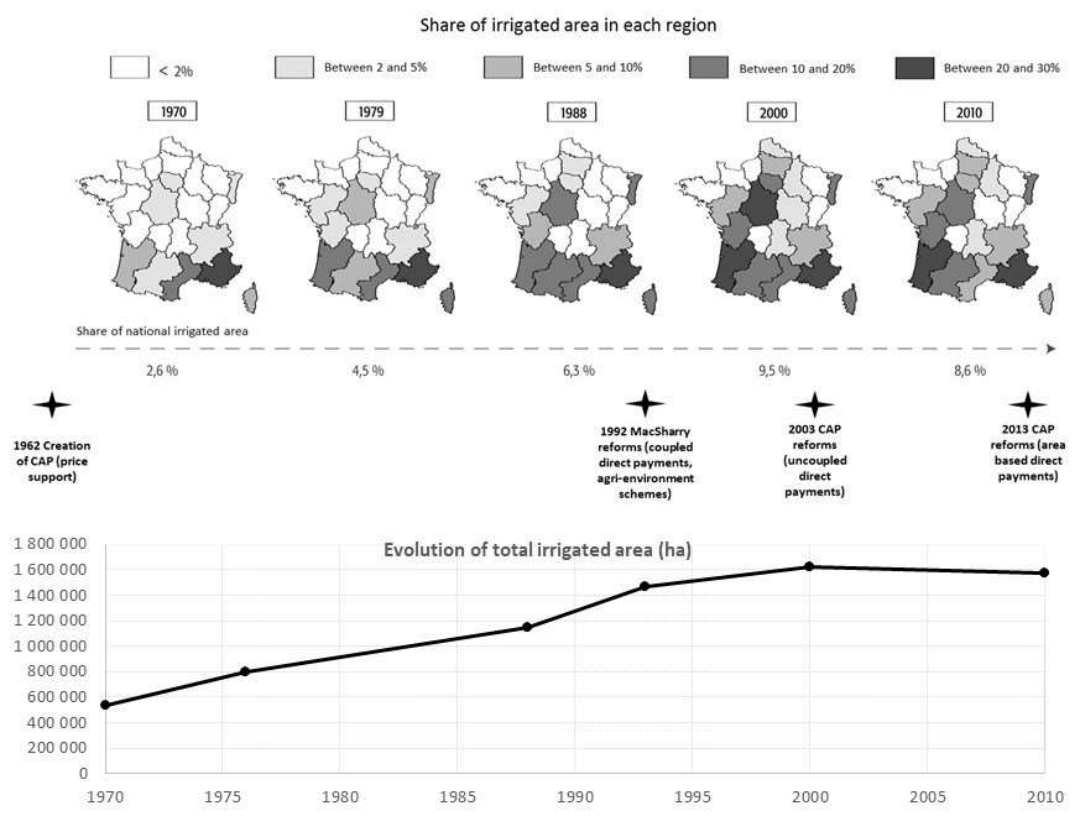

Figure 1. Key dates in the evolution of agricultural policies and irrigated areas in France (Source: modified from Lerbourg, 2012; Loubier et al., 2013)

The development of irrigation took three main forms (see also Amigues et al., 2006):

- Large schemes based on surface irrigation and managed by regional development agencies. Starting in the $1950 \mathrm{~s}$, these multi-purpose schemes aimed to supply domestic (including tourism), agricultural and industrial uses. The objective was to develop rural areas and reduce poverty in the southern and central regions of France. Large reservoirs, heavily subsidised, were constructed in the Alps, Pyrenees and Massif Central mountains as well as long distance canals and water transfers. Large water storage also helped maintain river flows during the low flow season and ensure sufficient water supply in downstream areas of the river basin.

- Collective irrigation schemes created and managed by irrigation associations. These schemes involved the derivation of surface water through canals and reservoirs, although some example existed of collective groundwater schemes ${ }^{1}$. Although collective irrigation schemes represent an old form of partnerships between farm businesses, public authorities

1 One such example is located in the Rhône county. See http://www.smhar.fr/presentation/historique-du-smhar/ 
took an active part in supporting their development in the second half of the $20^{\text {th }}$ century with up to $60 \%$ subvention rate in the $1960 \mathrm{~s}$.

- Private investments consisting of farm-level irrigation infrastructure and material. These investments included individual pumping units in surface water bodies or boreholes. Up until the early 1970s, these initiatives were mostly found in northern France where individual farm businesses had the financial means to support large investments individually (Martin, 1972). The 1980s saw the vast expansion of individual irrigation schemes, sometimes supported by public subsidies.

While collective schemes led to the greatest increase in irrigation between 1955 and 1965, individual initiatives became more popular from 1966 onwards (Martin, 1972). Between 1970 and 1988, individual initiatives represented two-third of the additional 400,000ha of irrigated areas (Loubier et al. 2013). During this period, groundwater pumping became a major source of agricultural water (see chapter 3).

Structural water deficits in the 1980s in many catchments and aquifers such as in the Beauce region (see chapter 5) or in the Marais Poitevin (see chapter 18) led to a change in water policy in France in 1992 (see chapter 3). However, reforms in agricultural policy did not remove the incentive for intensive cereal and maize production until the 2000s, leading to an increase in irrigated areas throughout the 1990s.

\section{The difficult reform of a productivist model: 1992 to 2003}

\section{A system of direct payments incentivising irrigation use}

In the 1980s, the CAP was increasingly criticised for its increasing burden on European public finance, environmental degradation and for the large food surpluses and international market distortions it created. The CAP underwent a first major transformation in 1992 under the MacSharry Reforms. The reforms led to a requirement on establishing set-asides, initially $15 \%$ of land on each farm ${ }^{2}$. Most importantly, a system of direct payments per hectare of farmed area would replace price support mechanisms. From 1996, payments were based on reference values set for each country at European level, then adjusted by a reference yield for each crop. In France, this reference yield was set at county level, i.e. higher payments were provided in counties with higher yield reference values. While the transition from price support to direct payments resulted in a net loss of income for farmers, a form of "coupling" on production (yield) was thus retained.

To compensate income loss to farmers who had invested in irrigation infrastructure and material in the 1980s and 1990s, French authorities created an additional premium on irrigated crops by mean of a regional reference yield value which accounted for the greater yield usually obtained from irrigated crops (Brun et al., 2006). As a result, direct payments for irrigated could be as high as $80 \%$ above the

\footnotetext{
${ }^{2}$ Set asides were abandoned at EU level in 2008.
} 
payments for dry cereal crops (Martin, 1996, see also Table 2 for examples of direct payments on dry and irrigated crops). Overall, the MacSharry reforms in France did not lead to the removal of all incentives to grow irrigated maize and cereals, which still benefited from higher CAP payments and better market conditions (Hurand, 1998; Simon, 1998).

By 2000, the extent of irrigated area reached 1.57 million ha (around $+40 \%$ from 1988) while the area equipped for irrigation covered 2.6 million ha (around $+50 \%$ from 1988). At this time, the development of irrigation occurred through a mix of collective and individual, farm-level schemes (Loubier et al., 2013). A significant development of groundwater abstraction can be observed during that period (see chapter 3).

Table 2. Income potential from cereal crops in the Midi-Pyrénées region in 2000/2001 (modified from Amigues et al. 2006)

\begin{tabular}{|l|c|c|c|c|}
\hline Crop & Average yield & Price (€/q) & $\begin{array}{c}\text { Product } \\
(\boldsymbol{\epsilon} / \mathbf{h a})\end{array}$ & $\begin{array}{c}\text { Direct pay- } \\
\text { ment }(\boldsymbol{\epsilon} / \mathbf{h a})\end{array}$ \\
\hline Sunflower (dry) & 28 & 26 & 734 & 337 \\
\hline Maize (dry) & 75 & 12 & 994 & 296 \\
\hline Maize (irrigated) & 110 & 12 & 1286 & 441 \\
\hline Sorgho (irrigated) & 85 & 9 & 805 & 441 \\
\hline Soja (irrigated) & 33 & 23 & 1219 & 531 \\
\hline
\end{tabular}

\section{The growth of agri-environmental measures in rural development policy}

The development of rural areas has been a priority for the French government since the immediate post Second World War period. Initially focused on modernising agriculture, rural development policy progressively broadened its scope to promote the development of rural infrastructure, the economic diversification of rural areas and, more recently, the management of natural resources and environmental protection (Perrin et al., 2003; Dechambre, 2007; Vandenbroucke, 2013).

At European level, a support scheme to farms in less favoured areas and regional structural funds to develop poorer regions were created in 1975, while the LEADER programme was created in 1991. Agri-environment schemes, created in 1988 and made compulsory for all member states in 1992, started to provide payments covering income loss and additional costs for measures increasing the environmental performance of farms. The 1999 reforms consolidated these multiple EU policy instruments around a coherent EU-wide rural development policy, also called the "second pillar" of the $\mathrm{CAP}^{3}$. EU rural development policy offered the possibility to

${ }^{3}$ The "first pillar" refers, since 1991, to the system of direct payments and other market interventions to stabilise the agricultural sector, see previous section. 
Member States to define their own priorities and select from 22 types of measures from which countries or regions could design their rural development programs according to their needs. Some measures aimed to modernise the agricultural or forestry sector while others aimed to strengthen rural economies at large or preserve natural resources (i.e. agri-environment schemes).

Building on localised experiments since 1989, French authorities established their first national agri-environment scheme in 1993 (Couvreur et al., 1999). This first scheme did not include any measures to reduce agricultural irrigation or tackle abstraction pressures. Nevertheless, several measures protecting biodiversity and reducing nitrogen or pesticide pollution could indirectly reduce abstraction pressures, such as crop diversification, crop rotation, and conversion of cereal crops into permanent grasslands. Measures preventing the conversion of grasslands into cropland also helped indirectly by reducing the incentive to convert to more waterintensive crops.

In contrast to the first scheme, the second agri-environment scheme (2000 -2006) explicitly integrated the issues of quantitative water management. One measure specifically aimed to reduce irrigated areas by replacing irrigated cereal crops with nonirrigated crops and another to reduce irrigation intensity by rotating cereal crops with non-irrigated leguminous crops. As a condition for payment, the farmer had to give up the associated abstraction allocation. However, the uptake of these measures was nearly non-existent (CNASEA, 2008); thus, their impact on reducing agricultural abstraction from groundwater and surface water was very limited.

Tackling production incentives, promoting good practice: 2003 onwards

\section{Des-incentivising irrigation in direct payments}

As discussed previously, CAP reforms in the 1990s maintained an incentive to increase agricultural production by coupling payments to crop yields. A subsequent reform in 2003 decoupled most direct payments. Two options were available to Member States: payments to farmers on an area basis (i.e. a uniform payment for all farms based on ha and type of crops produced) or on an historical basis (i.e. farms would receive the average of payments received in the period 2000-2002). In addition to direct decoupled payments, Member States could offer (limited) additional direct coupled payments to support specific crop production.

Because France opted for the historical approach, decoupled direct payments during the 2006-2013 CAP programming period remained higher for farmers who irrigated during the 2000-2002 reference period than for those farmers who did not. In addition, France opted to maintain some coupled payments, together with the irrigation premium, on cereal, oleaginous and protein crops (Boulanger, 2007).

As observed by Loubier et al. (2013), total irrigated area in France did not change significantly between 2000 and 2010 while the area equipped with irrigation has 
reduced by $12 \%$. Furthermore, during the same time, the total area of irrigated maize reduced by $8 \%$ while other irrigated cereal crops increased by $11 \%$ (Figure 2 ).
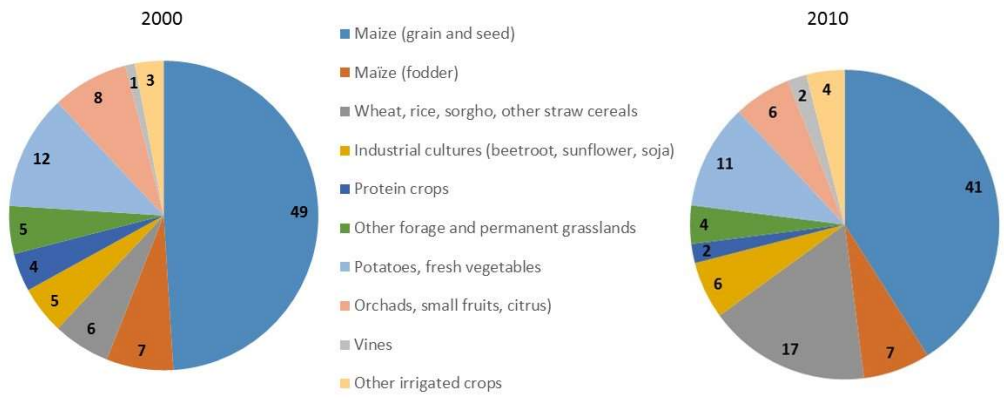

Figure 2. Main irrigated crops in France in 2000 and 2010. Source: modified from Loubier et al. 2013.

The latest CAP 2014-2020 aims to phase-out decoupled payments based on historical references towards fixed area-based payments. In France, decoupled payments should converge towards a unit value of $132 € /$ ha by 2020 (MAAF, 2017b). In addition, a compulsory "greening" top-up to the basic decoupled payments rewards crop diversification, the maintenance of permanent grasslands, and ecologically focus areas (e.g. field margins, buffer strips along rivers, hedges, N-fixing crops, green cover, landscape elements). Most coupled payments target livestock farming rather than crop production. Overall, the convergence in area payments between irrigators and non-irrigators and greening should further reduce historical policy incentives for irrigation.

In addition to the change in direct payments, the 2003 CAP reform attached cross compliance requirements to all direct payments to ensure farm compliance with a range of existing environmental and sanitary regulations and best practice. One conditionality, still applied to direct payments nowadays, relates to irrigation and requires that irrigators benefiting from CAP payments install water meters on their irrigation equipment and have a water abstraction authorisation from the authorities (or have made the relevant declaration) ${ }^{4}$.

\section{Promoting good practice in irrigation development and manage- ment}

The third French agri-environment scheme 2007-2013 offered similar measures to the 2000-2006 French agri-environment scheme (MAP, 2007). The uptake of agri-environment measures to reduce abstraction from irrigation was also very limited during the 2007-2013 scheme ( $<5,000 \mathrm{ha}$ ) (MAAF, 2017a). The on-going agrienvironment scheme 2014-2020 (MAAF, 2016) provides payments for introducing rotations of leguminous crops in irrigated cereal farming systems (i.e. from

${ }^{4}$ This conditionality has been applied since 2000 in France for irrigated maize. 
$78 € /$ ha/year to $215 € /$ ha/year depending on the amount of land targeted) (MAAF, 2016). A recent assessment of agri-environment schemes encouraging water savings in agriculture in five countries (including France) showed that the measures have not been effective and faced significant implementation barriers (OréadeBrèche, 2018).

Subsidies have long been available to construct, renovate and expand irrigation infrastructure for individual farms or collective schemes. Several conditions were attached to these subsidies in the 1990s and 2000s to account for stricter environmental requirements (e.g. impact assessments) and additional abstraction controls (see chapter 3). In particular, funding started to differentiate traditional reservoirs, which aim is to increase water supply to agriculture during dry periods, and "compensatory" reservoirs (in French, "réserves de substitution") which aim is to reduce the environmental impact of agricultural abstraction. Constructed outside the minor river bed, compensatory reservoirs are filled with surface and/or groundwater during the winter season and used in summer by farmers instead of direct pumping in surface water or groundwater bodies. Increased water storage should not lead to additional irrigated areas or additional abstraction.

Under rules established for measure $125 \mathrm{C}$ of the rural development plan 20072013 , irrigation projects leading to an increase in abstracted volumes could only be funded 1) if the river basin or aquifer had no water deficit and 2) where it could not impact the good status of the water body. In areas with water deficits, subsidies were only available to reduce abstraction pressure by temporally or spatially redistributing abstraction through water transfers or compensatory reservoirs. Overall, between 2006 and 2013, measure 125C was associated with 116 million $€$ worth of investment for 185 projects across France.

Subsidies for developing irrigation are still available in many of the on-going regional rural development plans 2014-2020. However, additional rules were attached, in particular to avoid an increase in irrigated areas following the construction of water storage or of more efficient irrigation scheme. Specifically, EU rural development plans must meet Article 46 of Regulation (EU) No 1305/2013 which requires that any investment in irrigation subsidised with EU funds, whether in new or existing irrigated areas, should meet a number of criteria which include:

- A river basin management plan is in place in the irrigated area and water metering is carried out on all abstraction points;

- Investments into existing installation result in potential water savings of at least $5 \%$ to $25 \%$ according to the technical parameters of the existing installation.

Any investment in areas where ground or surface waters are in less than good status for reasons related to water quantity (according to the river basin management plans under the EU Water Framework Directive) has to ensure an effective reduction in water use of at least $50 \%$ of the potential water saving. Net increases in 
irrigation area are only possible in areas where water bodies are not failing good status for reasons related to water quantity.

An evaluation made by Rouillard and Berglund (2017) demonstrated compliance with these requirements in several French rural development plans. Some plans are more ambitious. For example, the Poitou Charentes region, which partly administers the Marais Poitevin (see also chapter 18), only funds compensatory reservoirs, thereby aiming that new irrigation infrastructure funded via rural development policy does not lead to more abstraction in groundwater bodies.

\section{Collective approaches for quantitative groundwater manage- ment in agricultural areas}

\section{Establishing volumetric management of agricultural abstraction}

The favourable public policy support for irrigation in the second half of the $20^{\text {th }}$ century has led to a vast increase in agricultural irrigation and the creation of multiple abstraction points. More specifically, the importance of individual abstraction points ( 1.16 million ha in 2010 compared to 410,000 ha in collective or mixed irrigation schemes, see Loubier et al., 2013) represents a significant challenge to regulators whose monitoring and enforcement capacities are limited.

To increase the capacity to regulate agricultural abstraction, the 1992 Water Law established a requirement on irrigators to install water meters and request yearly abstraction licences (see chapter 3). The 1992 Water Law created two additional mechanisms for managing irrigation abstraction: temporary restrictions on abstractions to reduce abstraction pressures during drought situations and volumetric management of abstraction authorisations to tackle structural water deficits.

These instruments formed the basis for greater control on irrigation abstraction with the implementation of low flow and groundwater level targets, and spring and summer abstraction caps. Volumetric management in particular helped initiate some first schemes to control irrigation abstraction at aquifer level (e.g. Beauce) or catchment level. However, the instrument was voluntary and was thus first implemented for catchments and aquifers with intense water conflicts (e.g. Beauce, see chapter $5)$.

The 2006 Water Law made allocation caps compulsory in priority basins and aquifers, and requires agricultural water user associations ("Organisme Unique de Gestion Collective" or OUGC) which role is to facilitate the fair and equitable distribution of water allocated to irrigation between irrigators (see Chap. 3).

As the implementation of the 2006 Law progressed, large mismatches were confirmed in several catchments and aquifers between irrigation water demand and allocations available for irrigation water use. In the late 2000 s, several studies examined the economic impacts of reducing water allocations to the agricultural sector (Bouarfa et al., 2011; Danel, 2011; Hébert et al., 2012; Lejars et al., 2012). These 
studies suggested that the new restrictions could have a significant impact on farm businesses and agro-food chain that are highly dependent on irrigation.

\section{Emerging "territorial" contracts between agricultural water users and the state}

The response to reduce large structural water deficits while avoiding severe economic impact has usually been to promote the construction of compensatory water storage. However, building reservoirs is costly and is not economically viable without public subsidies in most regions in France (Loubier et al., 2011). The agricultural sector thus negotiated public support to build water storage where irrigation abstraction led to structural water deficits. In 2011, the main agricultural union requested $€ 1$ billion for the creation of $100 \mathrm{Mm} 3$ of water storage through compensatory reservoirs across France. The French government promised in return 100 million Euros to subsidise the creation of $40 \mathrm{Mm} 3$ of water storage (DGALN, 2011). In the Adour-Garonne river basin, a regional agreement was signed the same year to allow the subsidised construction of up to $69 \mathrm{Mm} 3$ in 59 reservoirs; no quantitative objective for water savings were set (Aypahssorho et al., 2016).

Plans to build reservoirs were met with strong resistance by non-agricultural actors, citing the visual and environmental (i.e. affecting winter flow dynamics) impact of reservoirs, high public costs, and the explicit support to an intensive form of agriculture (see also Granjou \& Garin, 2006). Following national elections in 2012, the French government imposed a ban on state funding for compensatory reservoirs. A parliamentary investigation was set up to identify "a new vision for quantitative water management in agriculture".

The resulting report (Martin, 2013) and stakeholder consultation led to a first ministerial decree in 2015 (RF, 2015) setting out new conditions on water agencies funding of compensatory reservoirs. More specifically, funding for compensatory reservoirs should be justified through local "projets de territoire" (i.e. "territorial" projects), presenting a comprehensive strategy to meeting quantitative management targets for a given groundwater body or catchment strategy through a balanced combination of supply and demand management measures.

The "projet de territoire": an integration of agricultural and water policies, and regional development?

As defined in the governmental decree of 2015, the "projet de territoire" must:

- Aim for a balanced quantitative management of water resources, considering the impacts of climate change; objectives must include quantified targets on reducing total abstraction;

- Take into account the chemical and ecological status of water bodies, notably by implementing agro-ecological systems and crop diversification;

- Implement a variety of measures, including water demand management, changes in crop production and rotation, development of alternative agro- 
food value chains, water efficiency (e.g. drip irrigation, irrigation management) and infrastructure modernisation; water supply options should not only include new reservoirs and transfers but also water reuse;

- Be an outcome of a dialogue between all local actors.

The initial intention of the "projet de territoire" was to encourage an integrated approach to planning water storage for agriculture, taking into account the environmental and socio-economic impacts of the proposed infrastructure. The project should not only have an environmental objective, but also add "value" to the area in social and economic terms. For example, the planning should shed light on the economic benefits of irrigation and on the value for the local economy of non-irrigated agri-food value chains (RF, 2015). Thus, in theory, the "projet de territoire" is at the crossroads of several planning processes, including those related to river basin and catchment plans, agricultural and rural development policies, and regional development plans (Figure 3).

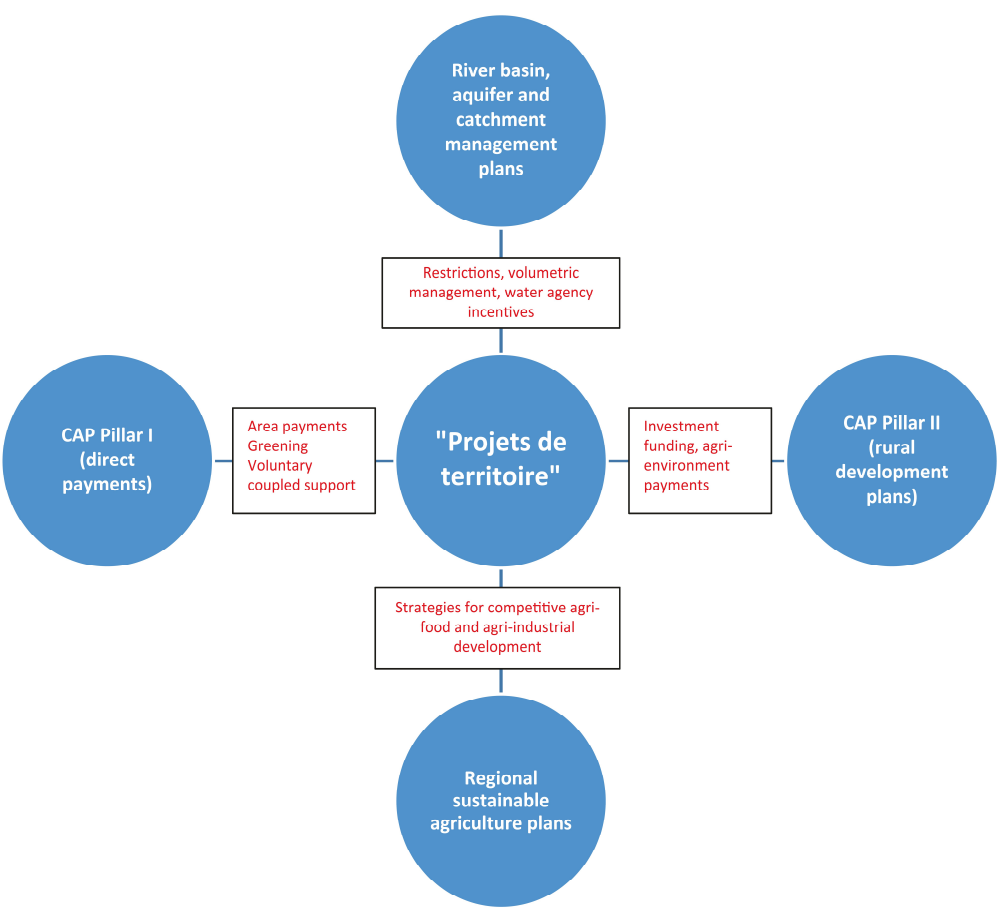

Figure 3. The "projet de territoire" at the crossroad of water, agricultural, rural development and regional development policies

A recent ministerial communication (Bisch et al., 2018) and governmental decree (RF, 2019) broadens the scope of the "projet de territoire". It should consider quantitative targets for all sectors (e.g. agriculture, drinking water, industrial) and 
propose a balanced combination of measures across those. It should also integrate qualitative issues in water management (e.g. diffuse and point source pollution). Regarding agriculture, the communication reinforces the need to adapt agricultural production systems. Water savings should take priority over water storage or transfers. Finding synergies between sectors are encouraged (e.g. reuse of wastewater in agriculture, creation of multi-use water storage). The building of water storage for irrigation purposes is justified if it contributes more widely to regional development.

The "projet de territoire" builds on previous experiences in the Loire-Bretagne and the Rhone-Mediterranean-Corsica river basins where quantitative management contracts were used to manage structural water deficits in priority catchments and aquifers, i.e. respectively "Contrat Territorial de Gestion Quantitative" (CTGQ) and "Plan de Gestion des Ressources en Eau" (PGRE). Evaluations of the implementation of the CTGQ and PGRE have highlighted their value in raising awareness of the issues linked to intensive agricultural water use (Epices and AScA, 2015; Epices et al., 2017). However, several limitations were also found, one of which being that projects tend to focus on creating reservoirs (in the case of CTGQ) and water transfers (in the case of PGRE) rather than securing real water savings.

More recently, Bisch et al. (2018) showed that the "projet de territoire" concept did not help in overcoming conflicts around the management of irrigation water: out of 60 existing projects (including CTGQ and PGRE), only five have been validated and implemented. More significantly, most measures proposed in those projects focused on building water storage or water transfers, rather than securing water savings.

For example, in the Marais Poitevin area where over-abstraction of groundwater has been a recurring problem since the 1980s (see also chapter 18), three CTGQs were adopted in 2012 . $18.48 \mathrm{Mm}^{3}$ of new compensatory storage (e.g. filled with groundwater abstracted in winter and used for spring and summer irrigation) were planned in 2012. This compared to $1.56 \mathrm{Mm}^{3}$ of planned water savings ${ }^{5}$ to be achieved through:

- Carry out farm-level audits to determine the adequate modifications to irrigation techniques and crop rotations to reduce overall water consumption;

- Develop tensiometer-based irrigation and more water efficient irrigation (e.g. drip irrigation);

- Encourage the uptake of more water efficient crops during the spring and summer season (e.g. spring crops, irrigated grasslands, sorghum) and adapt sowing dates depending on spring hydrological situation;

- Improve communication on the quantitative status of the water resources and offer training in irrigation management.

Table 3 presents planned and estimated water savings for two sub-basins of the Marais Poitevin. It shows that most savings were achieved through the application

\footnotetext{
${ }^{5}$ Total calculated from the Sèvre Niortaise, Lay and Vendée CTGQs
} 
of tensiometer-based irrigation to optimise water use. The implementation of the agri-environmental measure to stop irrigation, which offered better payment conditions in the 2007-2013 than the 2000-2006 (see above), also contributed to reduce water abstraction allocations by $1.4 \mathrm{Mm}^{3}$.

Measures modifying cropping patterns and types are taking longer to implement, in part due to unwillingness to modify existing farm management practices, market demand, and requirements from agro-food chains. Although agricultural diversification has been promoted since the 1990s for biodiversity reasons (Simon, 1998), few farmers have taken up these options (Aypahssorho et al., 2016) and this approach does not appear prominently in the CTGQs.

Table 3. Planned and estimated water savings in the Lay and Vendée sub-basin of the Marais Poitevin. Source: SMMP \& CA Vendée (2012a, b); CA Vendée (2017)

\begin{tabular}{|l|c|c|}
\hline Measure & $\begin{array}{c}\text { Planned saving } \\
\text { in CTGQ } \mathbf{( m}^{\mathbf{3}} \mathbf{)}\end{array}$ & $\begin{array}{c}\text { Estimated sav- } \\
\text { ing } \mathbf{2 0 1 7}\left(\mathbf{m}^{\mathbf{3}}\right)\end{array}$ \\
\hline Tensiometer-based irrigation & 427000 & 862500 \\
\hline Agri-environment measure on irrigation & 300000 & 300000 \\
\hline Earlier sowing date & 305780 & 173000 \\
\hline Spring crop variety, water stress resistant crops & 305420 & 147500 \\
\hline Crop diversification & 162000 & 48000 \\
\hline Total & $\mathbf{1 5 0 0 2 0 0}$ & $\mathbf{1 4 0 5 5 0 0}$ \\
\hline
\end{tabular}

Recent research evaluating four alternatives to solving water imbalance suggest strong trade-offs between environmental effectiveness and economic impacts on agriculture (Allain et al., 2018). The four alternatives included: reducing irrigated areas, assisting irrigation with decision-support tools, implementing crop rotations and merging water storage into later reservoirs. The study showed that crop rotations (in this case study, switching maize monoculture into a sunflower-straw cereal-oilseed rape and maize rotation) had the greatest potential for long term environmental preservation but the highest impact on farm economies. The study however focused on changes to gross margin in a similar production system. It did not explore the possible cushioning long term effect of a transformation of the production system towards higher value crops and value chains.

\section{Conclusion}

The chapter presented the evolution of French and EU agricultural policies, their role in irrigation management, and the consequences on groundwater and surface water use. Three phases were identified.

The first phase, from the immediate post-war to the early 1990s, is associated with a vast development of irrigation across France. The increase in groundwater use was associated with the uptake of complementary irrigation in central and northern regions of France to increase the productivity of cereal and maize farming. The 
second phase, mainly in the 1990 s, is a transitional period, during which agricultural policies maintained an explicit support to irrigated farming. Issues of overexploitation resulted in the adoption of the first major policies to monitor and regulate groundwater abstraction and install water metering on irrigation equipment. The current phase $(2000 \mathrm{~s}-2010 \mathrm{~s})$ is associated with the progressive removal of incentives for irrigated crops, while ambiguous objectives remain in rural development policies: on the one hand, some agri-environmental measures tackling agricultural pressures on water quantity are proposed; on the other, funding is available for the construction of (non-compensatory) reservoirs to support irrigated farming. Conflicts around the funding of compensatory reservoirs also show that this approach is not devoid of controversy.

More broadly, the chapter highlighted that French authorities have opted for a decentralised form of governance on agricultural water use though the use of local "contracts" and "projets de territoire" to achieve a balance between irrigation water demand and availability. The policy framework thus sets out a comprehensive strategy to manage irrigation water. However, in practice, water quantity targets are mostly met via the building of compensatory reservoirs and via efficiency gains (e.g. improvements in irrigation techniques). Less emphasis is given to modifying production types and optimising their commercialisation in order to enhance the economic sustainability of a water efficient agricultural sector (i.e. increasing the value added per water consumed).

The liberalisation of agricultural markets and increased meteorological variability due to climate change are likely to increase the demand for irrigated water and water storage to secure fodder production and high quality crop. To achieve future quantitative groundwater targets, it is essential to ensure a coherent set of agricultural and water policy instruments. Policy action should not solely focus on water supply management (e.g. compensatory reservoirs, water allocations) or the efficiency of irrigation systems, but also on production choices made by farmers. Future work should thus explore in more detail the potential of agricultural diversification, alternative value chains, agro-food systems and rural development trajectories in meeting quantitative groundwater management targets.

Acknowledgement This work is part of the RURECO project ("Institutions for groundwater dependent rural economies"), funded by the Marie Skłodowska-Curie Action Individual Fellowship of the EU's Horizon 2020 Programme for Research, Technological Development and Demonstration under Grant Agreement no. 750553. 


\section{References}

AFB (Agence Francaise pour la Biodiversité) (2017). Bulletin $n^{\circ} 2$ : prélèvements quantitatifs sur la resource en eau. Edition Mars 2017.

Allain, S., Obiang Ndong, G., Lardy, R., \& Leenhardt, D. (2018). Integrated assessment of four strategies for solving water imbalance in an agricultural landscape. Agronomy for Sustainable Development, 38(6), 12.

Amigues J.P., P. Debaeke, B. Itier, G. Lemaire, B. Seguin, F. Tardieu, and Thomas, A. (éditeurs) (2006). Sécheresse et agriculture. Réduire la vulnérabilité de l'agriculture à un risque accru de manque d'eau. Expertise scientifique collective, Rapport, INRA, France, 380pp.

Aypahssorho, H., Caude, G. and Etaix, C. (2016). Le Marais poitevin : état des lieux actualisé des actions gouvernemental 2003-2013 et orientations. Ministère de l'Environnement, de 1'Energie et de la Mer, Paris, France, 236pp.

Bisch, P.E., Hubert, L., Mailleau, C., Denier-Pasquier, F., Servant, L. (2018). Cellule d'expertise relative à la gestion quantitative de l'eau pour faire face aux épisodes de sècheresses. Ministère de la Transition Ecologique et Solidaire et Ministère de l'Agriculture et de l'Alimentation, Paris, France, 128pp.

Bouarfa, S., Brunel, L., Granier, J., Mailhol, J.C., Morardet, S., and Ruelle, P. (2011). Evaluation en partenariat des stratégies d'irrigation en cas de restriction des prélèvements dans la nappe de Beauce (France). Cahier de l'Agriculture, 20, n 1 2, 124-129.

Boulanger, P. (2007). Subventions directes agricoles et gestion quantitative des ressources en eau. Policy brief GEMPB-2007-4. Groupe d'économie mondiale, Septembre 2007.

Brun, A., Lasserre, F. and Bureau, J.C. (2006). Mise en perspective comparée du développement de l'irrigation aux Etats-Unis et en France. Géocarrefour, 81(1), pp. 5-14. doi : 10.4000/geocarrefour.1701

CA (Chambre d'Agriculture) Vendée (2017). Bilan CTGQ du Bassin Lay et Vendée. Présentation.

CNASEA (Centre National pour l'Aménagement des Structures des Exploitations Agricoles) (2008). Evaluation ex post du Plan de Développement Rural National. Soutien à l'agroenvironnement. Synthèse de l'évaluation. Rapport final définitif. Paris, France, Décembre 2008.

Couvreur, M., Mitteault, F., Michel, P. (1999). Les mesures agri-environnementales mises en œuvre en France. Economie rurale, 249, pp. 6-10. doi : 10.3406/ecoru.1999.5053.

Danel, J.B. (2011). Conséquences sur les filières agricoles et agroalimentaires de l'atteinte des objectifs quantitatifs de la Directive cadre sur l'eau et du SDAGE dans le bassin Adour-Garonne. Conseil général de l'alimentation, agriculture et des espaces ruraux, Paris, France, 38pp.

Dechambre, B. (2007). La PAC et le développement rural. L'agriculture : de nouveaux défis. Editions 2007, INSEE. Available at https://www.insee.fr/fr/statistiques/1372302? sommaire=1372309 (Accessed 01/04/2018). 
DGALN (Direction Générale de l'Aménagement, du Logement et de la Nature) (2011). Plan d'adaptation de la gestion d'eau: soutien à la création de retenues d'eau et à l'adaptation des cultures. Ministère de l'Ecologie et Ministère de l'Agriculture, Paris, France.

Epices and AScA (2015). Evaluation des politiques publiques de l'agene de l'eau Loire-Bretagne. Rapport final - Evaluation du contrat territorial. 164pp.

Epices, AScA, Artélia (2017). Evaluation de la politique de réduction des déséquilibres quantitatifs de la ressource en eau. Synthèse. Bassins Rhône-Méditerranée et de Corse. 9pp.

Erdlenbruch, K., Loubier, S., Montginoul, M., Morardet, S., and Lefebvre, M. (2013). La gestion du manque d'eau structurel et des sécheresses en France. Sciences Eaux et Territoires, 11, pp. 78-85.

Granjou, C. and Garin, P. (2006). Organiser la proximité entre usagers de l'eau : le cas de la gestion volumétrique dans le bassin de la Charente. Développement durable et territoires, dossier 7.

Hébert N., Grandmougin B., Loubier S., Graveline N., Marsac S., Amen J.-F. and Brunel L. (2012). «Réforme des autorisations de prélèvement dans le bassin Adour-Garonne : impacts sur l'économie agricole ", Agronomie, Environnement \& Sociétés, 2, 2, pp. 113-126.

Hurand, P. (1998). La PAC et l'irrigation des grandes cultures. Aménagement et Nature, 130, pp. 35-48.

Janin, J.L. (1996). L'irrigation en France depuis 1988. La Houille Blanche, 8, pp. 27-34. Doi : 10.1051/1hb/1996083.

Lejars, C., Fusillier, J. L., Bouarfa, S., Brunel, G., Rucheton, G., Girard, X., et al. (2012). Impacts de restrictions en eau d'irrigation sur les exploitations et les filières agricoles en Beauce. Agronomie, Environnement et Sociétés, 2(2), 139-154.

Lerbourg, L. (2012). Des surfaces irrigables en baisse à partir de 2000. Ministère de l'Agriculture, de l'Agroalimentaire et de la Forêt. Agreste Primeur, numéro 292, Novembre 2012, Montreuil, France.

Loubier, S., Poussin, J.C., Gleyses, G., Le Mat, O., and Garin, P. (2011). Faut-il subventionner la création de réserves d'eau pour l'irrigation? Une approche par la modélisation microéconomique. Cahier de l'Agriculture, 20, pp. 157-164.

Loubier, S., Campardon, M., Morardet, S. (2013). L'irrigation diminue-t-elle en France ? Premiers enseignements tirés du recensement agricole de 2010. Science eaux et territoires, 11, pp. 12-19.

MAAF (Ministère de l'Agriculture, de l'Alimentation et de la Forêt) (2016). Plan de Développement Rural Français - Cadre National. Version 03/08/2016. Paris, France, 950pp.

MAAF (Ministère de l'Agriculture, de l'Alimentation et de la Forêt) (2017a) . Evaluation ex post du programme de développement rural hexagonal (PDRH) Programme FEADER 2007-2013. Rapport final, Tome 3. Paris, France, 163pp.

MAAF (Ministère de l'Agriculture, de l'Alimentation et de la Forêt) (2017b). La Politique Agricole Commune, Cap sur la PAC 2015-2020. Version révisée de Mars 
2017. Available on http://agriculture.gouv.fr/la-pac-en-un-coup-doeil (Accessed 20/04/2018).

MAP (Ministère de l'Agriculture et de la Pêche) (2007). Plan stratégique national de développement rural 2007-2013. Version 16 avril 2007. Paris, France, 178pp.

Martin, J. (1972). L'évolution de l'irrigation en France. Revue de géographie alpine, 60(3), pp. 419-443. doi : 10.3406/rga.1972.1276

Martin, Y. (1996). Rapport sur la gestion durable des eaux souterraines. Ministère de 1'Industrie, de la Poste et des Télécommunications. Conseil Général des Mines, Paris, France, 74pp.

Martin, P. (2013). La gestion quantitative de l'eau en agriculture : une nouvelle vision, pour un meilleur partage. Parlemantaire en mission auprès du gouvernement, Paris, France, 87pp.

Oréade-Brèche. (2018). Economiser l'eau pour l'irrigation par les changements de pratiques agricoles : analyse comparée de politiques publiques et pistes d'amélioration en France. Etude n¹5.14., Paris, France, 86pp.

Perrin, J., Malet, J., Brun, G., Guérin, M., Ruas, J.F., Templé, P., and Theurkauff, MC. (2003). Rapport de l'instance d'évaluation des politiques de développement rural. Conseil National de l'Evaluation, Commissariat Général du Plan. Paris, France, 479pp.

RF (République Française) (2015). Instruction du Gouvernement du 4 juin 2015 relative au financement par les agences de l'eau des retenues de substitution. NOR : DEVL1508139J.

RF (République Française). (2019). Instruction du Gouvernement du 7 mai 2019 relative au projet de territoire pour la gestion de l'eau. NOR: TREL1904750J.Rieu, T. and Arlot, M.P. (1992). Le poids de l'agriculture dans la répartition et l'usage de l'eau. Economie rurale 208, pp. 57-60. Doi : 10.3406/ecoru.1992.4452.

Rouillard, J.J. and Berglund, M. (2017). European level report: Key descriptive statistics on the consideration of water issues in the Rural Development Programmes 2014-2020. European Commission, Brussels, Belgium.

Simon, G. (1998). Le Marais Poitevin. Conseil Général des Ponts et Chaussées. Paris, France, 22pp.

SMMP (Syndicat Mixte Marais Poitevin) \& CA Vendée. (2012a). Contrat Territorial Gestion Quantitative Secteur Lay. Période 2013-2017.

SMMP (Syndicat Mixte Marais Poitevin) \& CA Vendée. (2012b). Contrat Territorial Gestion Quantitative Secteur Vendée. Période 2013-2017.

Vandenbroucke, P. (2013). Transformations de l'unité de production agricole : d'une exploitation sectorielle à une exploitation agricole territoriale. Exploitations agricoles, agriculteurs et territoires dans les Monts du Lyonnais et en Flandre intérieure de 1970 à 2010. Thèse de Doctorat en Géographie, Aménagement et Urbanisme. Université Lumière Lyon 2, Lyon, France, 607pp. 